\title{
Aspartylglycosaminuria: a review
}

\author{
Maria Arvio ${ }^{1,2,3^{*}}$ and Ilkka Mononen ${ }^{4,5,6}$
}

\begin{abstract}
Aspartylglucosaminuria (AGU), a recessively inherited lysosomal storage disease, is the most common disorder of glycoprotein degradation with a high prevalence in the Finnish population. It is a lifelong condition affecting on the patient's appearance, cognition, adaptive skills, physical growth, personality, body structure, and health. An infantile growth spurt and development of macrocephalia associated to hernias and respiratory infections are the key signs to an early identification of AGU. Progressive intellectual and physical disability is the main symptom leading to death usually before the age of 50 years.

The disease is caused by the deficient activity of the lysosomal enzyme glycosylasparaginase (aspartylglucosaminidase, AGA), which leads to a disorder in the degradation of glycoasparagines - aspartylglucosamine or other glycoconjugates with an aspartylglucosamine moiety at their reducing end - and accumulation of these undegraded glycoasparagines in tissues and body fluids. A single nucleotide change in the AGA gene resulting in a cysteine to serine substitution (C163S) in the AGA enzyme protein causes the deficiency of the glycosylasparaginase activity in the Finnish population. Homozygosity for the single nucleotide change causing the C163S mutation is responsible for $98 \%$ of the AGU cases in Finland simplifying the carrier detection and prenatal diagnosis of the disorder in the Finnish population. A mouse strain, which completely lacks the Aga activity has been generated through targeted disruption of the Aga gene in embryonic stem cells. These Aga-deficient mice share most of the clinical, histopathologic and biochemical characteristics of human AGU disease. Treatment of AGU mice with recombinant AGA resulted in rapid correction of the pathophysiologic characteristics of AGU in non-neuronal tissues of the animals. The accumulation of aspartylglucosamine was reduced by up to $40 \%$ in the brain tissue of the animals depending on the age of the animals and the therapeutic protocol. Enzyme replacement trials on human AGU patients have not been reported so far. Allogenic stem cell transplantation has not proved effective in curing AGU.
\end{abstract}

Keywords: Aspartylglucosaminuria, Aspartylglycosaminuria, Lysosome, Lysosomal strorage, Aspartylglucosamine, Glycoasparagine, Glycosylasparaginase, Aspartylglucosaminidase, Glycoprotein degradation

\section{Background}

Aspartylglykosaminuria (AGU) has been found to be the most common recessively inherited disease in the Finnish population. It has been described in early 1960's and so far approximately 260 Finnish patients and single patients representing all races and several nationalities have been identified with this genetic defect. The clinical, molecular genetic and biochemical research data is reviewed in this paper for this often poorly recognized but still rather commonly occurring disability. Practical implications of the available knowledge onto everyday patient care are also outlined.

\footnotetext{
* Correspondence: maria.arvio@phsotey.fi

${ }^{1}$ Päijät-Häme Social Welfare \& Healthcare Joint Municipal Board, Lahti, Finland

${ }^{2}$ KTO, The Special Welfare District of Southwestern Finland, Paimio, Finland Full list of author information is available at the end of the article
}

\section{Review \\ Disease name/synonyms \\ - Aspartylglucosaminuria (AGU) \\ - Aspartylglycosaminuria (AGU) \\ - Glycosylasparaginase deficiency \\ - Aspartylglucosaminidase deficiency \\ - AGA deficiency \\ - Glycoasparaginase deficiency}

\section{Definition}

Aspartyglycosaminuria (AGU) was first described in 1968 in a British family with two seriously intellectually disabled children, who excreted large amounts of aspartylglucosamine (2-acetamido-1-( $\beta$ '-L-aspartamido)-1,2-didieoxyglucose; GlcNAc-Asn) in their urine [1]. At the same time in 
Finland, a screening study concerning amino acids in urine among 2177 intellectually disabled individuals identified 11 patients with similar clinical symptoms and excretion of large amounts of an unknown compound containing aspartic acid in their urine [2]. The combined evidence from the Finnish and British patients demonstrated that all of them suffered from AGU. Eventually this led to the realization that enrichment of AGU had occurred in the Finnish population.

AGU is the most common lysosomal storage disease caused by a disorder in degradation of glycoproteins. Glycoproteins commonly contain carbohydrate moieties, which are joined to protein moiety by means of an N-glycosidic bond between amino acid L-asparagine and monosaccharide $\mathrm{N}$-acetylglucosamine. AGU is caused by deficient activity of the lysosomal enzyme glycosylasparaginase that cleaves the $\mathrm{N}$-glycosidic bond between the L-asparagine and $\mathrm{N}$-acetylglucosamine moieties of GlcNAc-Asn. This enzyme deficiency results in the accumulation of undegraded aspartylglucosamine and a series of other glycoasparagines i.e., glycoconjugates containing an L-asparagine moiety linked to the carbohydrate chain in tissues and body fluids of the affected $[3,4]$.

\section{Population genetics}

AGU belongs to the group of disorders referred to as the Finnish disease heritage [3-6]. Approximately 260 patients have been reported in Finland (2014 population: 5.3 million), and 160 of those are currently alive. Approximately 200-300 living AGU patients are currently known worldwide. Approximately 30 patients are known to be living in Sweden and Norway, and at least some of them are descendants of Finns [7]. AGU frequency of 1 in 3643 was found in a study of children in eastern Finland corresponding to a carrier rate of 1 in 30 in that population [8]. In about $98 \%$ of the Finnish AGU patients, the disease is caused by a single point mutation in the glycosylasparaginase gene (see later). It is estimated that the carrier of this mutation is 1 in 50-60 among Finns $[9,10]$. Annually, 13 children with AGU are born in Finland implying a prevalence of $1.7-5 / 100.000$ live births in its population. Single, but increasing number of AGU patients have been reported globally and in all races suggesting that the disease may be underdiagnosed. In many of these patients the disease-causing gene mutation is different from that of common in the Finnish population (see later).

\section{Clinical description}

AGU is a neuropsychiatric, generalized disease with a progressive course affecting the whole body and resulting in premature aging. A detailed clinical picture according to the age covering the patients' cognition, speech, self-help, motor skills, personality, growth, mouth, head and face, skin, connective tissue, state of health, as well as laboratory and X-ray findings is given in Tables 1 and 2 [11-13]. The speed of progression of AGU varies between separate patients being a little slower among females.

At birth, the children with AGU are usually healthy with normal birth measurements. An infantile growth spurt (Fig. 1) and increased head circumference (Fig. 2) are the first symptoms [14] associated to hernias and respiratory infections are the key signs to an early identification of AGU. In childhood AGU appears as delayed speech development, poor motor coordination and exceptional placidity or periods of hyperactivity [15]. On the average, the clinical diagnosis of AGU is made at the age of 5 years. The developmental profile comprises three phases: i) Firstly, an abnormally slow but positive development up to the age of 13-16 years, ii) a stable period with a mild and slow decline up to the age of 2528 years, and finally iii) a rapid decline after the age of 30 years. In psychological tests, the under school-aged AGU children score at a subnormal intellectual disability level, school-aged children at a mild intellectual disability level, teenagers and young adults at a moderate level, adults at a severe level, and the middle aged at a profound intellectual disability level $[16,17]$. The patient's appearance, facial features and body shape as well as their personality are characteristic to the disease (Fig. 3 a-b) [18]. The oral health is impaired in almost all adult patients. Every third patient suffers from epileptic seizures (often nocturnal frontal lobe epilepsy), every fifth from psychiatric disorders and every $20^{\text {th }}$ from rheumatoid arthritis as an associated condition [19-23]. There are many laboratory and imaging findings characteristic to AGU, which are of no clinical significance. It is useful to be aware of these so that the patient is not referred for further examination, for example bone marrow aspiration due to a low white blood cell count in their peripheral blood. Ribs are thick and misshapen, while long bones are thin. The vertebra may show skeletal abnormalities. The skull is often thick and as the patient ages, the loss of brain cells is evident. The disease has a characteristic MRI finding [24]. A special phenomenon is the reduction or shrinking of head circumference as the patient ages (Fig. 2) [25].

\section{Molecular genetics}

The primary defect in AGU is a mutation in the AGA gene comprising 9 exons and located on 4q34.3. The AGA sequence is highly conserved in evolutionary terms [26].

In the Finnish patients with AGU Mononen et al. [27], Fisher and Aronson [28] and Ikonen et al. [29] independently identified homozygosity for two point mutations (G482A and G488C) in the cDNA of glycosylasparaginase. The first nucleotide change results in the replacement of arginine by glutamine (R161Q) and the second change results in a cysteine-to-serine substitution (C163S) in the 
Table 1 Progressive nature of AGU: Growth, cognition, personality, speech, self-help, and motor skills according age. ID = intellectual disability

\begin{tabular}{|c|c|c|c|c|c|c|}
\hline $\begin{array}{l}\text { Age in } \\
\text { years }\end{array}$ & Growth & Cognition & Personality & Speech & Self-help & Motor skills \\
\hline$<2$ & $\begin{array}{l}\text { Early growth spurt }+1- \\
+2 \text { sd }\end{array}$ & Normal & "An easy baby" & Normal & Normal & Stiffness in hips \\
\hline $2-5$ & $+1 S D$ & Subnormal & $\begin{array}{l}\text { Well-behaved and } \\
\text { fussy }\end{array}$ & Delayed & Delayed & Walks clumsily \\
\hline $6-9$ & $0-+1 s d$ & Mild ID & $\begin{array}{l}\text { Talkative, kind, } \\
\text { stubborn }\end{array}$ & Unclear & Delayed & $\begin{array}{l}\text { Can bike and ski, not } \\
\text { skate }\end{array}$ \\
\hline $10-15$ & $\begin{array}{l}\text { Slight and short } \\
\text { pubertal growth spurt, } \\
\text { early menarche, } \\
\text { macro-orchidism }\end{array}$ & Moderate ID & $\begin{array}{l}\text { Fond of children, } \\
\text { joyful }\end{array}$ & Clear & $\begin{array}{l}\text { Independent in } \\
\text { toileting, dresses } \\
\text { and undresses }\end{array}$ & No change \\
\hline $16-19$ & $\begin{array}{l}\text { Growth ceases, } \\
-1 S D\end{array}$ & $\begin{array}{l}\text { Moderate/severe } \\
\text { ID }\end{array}$ & Tends to withdraw & "Soft" & $\begin{array}{l}\text { Able to do little } \\
\text { shopping }\end{array}$ & No change \\
\hline $20-24$ & Girls gain weight & Severe ID & $\begin{array}{l}\text { Attached to parents, } \\
\text { shows no interest } \\
\text { to opposite sex }\end{array}$ & "Soft" & $\begin{array}{l}\text { Able to move outdoors } \\
\text { in familiar surroundings }\end{array}$ & $\begin{array}{l}\text { No more biking nor } \\
\text { skiing }\end{array}$ \\
\hline $25-34$ & No change & Severe ID & Calm, passive & $\begin{array}{l}\text { Vocabulary } \\
\text { decreases }\end{array}$ & $\begin{array}{l}\text { Active and passive } \\
\text { periods }\end{array}$ & $\begin{array}{l}\text { May walk without a } \\
\text { goal }\end{array}$ \\
\hline $35-44$ & No change & Severe ID & Confused & Few words & Constant need of help & $\begin{array}{l}\text { Legs seem not to } \\
\text { respond }\end{array}$ \\
\hline $45+$ & Loss of weight & Profound ID & $\begin{array}{l}\text { Sits still for hours, } \\
\text { angry when } \\
\text { disturbed }\end{array}$ & No speech & Constant need of help & $\begin{array}{l}\text { Poor balance/wheel } \\
\text { chair }\end{array}$ \\
\hline
\end{tabular}

Table 2 Progressive nature of AGU: mouth, head and face, skin, connective tissue, health and test findings according age

\begin{tabular}{|c|c|c|c|c|c|c|}
\hline $\begin{array}{l}\text { Age } \\
\text { in } \\
\text { years }\end{array}$ & Mouth & $\begin{array}{l}\text { Head and } \\
\text { Face }\end{array}$ & Skin & $\begin{array}{l}\text { Connective } \\
\text { tissue }\end{array}$ & State of health & Test findings, brain MRI \\
\hline$<2$ & Normal & $\begin{array}{l}\text { Macrocephalia, } \\
\text { broad } \\
\text { mandiple, } \\
\text { short and } \\
\text { broad nose }\end{array}$ & Facial erythema & $\begin{array}{l}\text { Hernia, } \\
\text { planovalgus, } \\
\text { clubfoot }\end{array}$ & $\begin{array}{l}\text { Respiratory infections, } \\
\text { diarrhoea }\end{array}$ & Vacuolated cells in all tissues \\
\hline $2-5$ & $\begin{array}{l}\text { Large tongue, broad } \\
\text { dental arches, food } \\
\text { retention }\end{array}$ & $\begin{array}{l}\text { Generous } \\
\text { cheeks, } \\
\text { periorbital } \\
\text { fullnes }\end{array}$ & $\begin{array}{l}\text { Piezogymic } \\
\text { papules in heels, } \\
\text { white spots }\end{array}$ & $\begin{array}{l}\text { Tapered fingers, } \\
\text { lordosis }\end{array}$ & $\begin{array}{l}\text { Respiratory infections, } \\
\text { diarrhoea }\end{array}$ & $\begin{array}{l}\text { Delayed myelination, } \\
\text { decreased } 72 \text { signal intensity } \\
\text { of the thalami }\end{array}$ \\
\hline $6-9$ & Gingivitis, oral candida & No change & No change & $\begin{array}{l}\text { Bulging } \\
\text { abdomen, } \\
\text { knock-knees }\end{array}$ & Benign subcutaneous tumors & $\begin{array}{l}\text { Thick and misshapen ribs, } \\
\text { vertebral dysplasia }\end{array}$ \\
\hline $10-15$ & Gingival overgrowts & No change & Facial seborrhoea & $\begin{array}{l}\text { Broad and low } \\
\text { ball of foot }\end{array}$ & Arthritis rheumatoides & $\begin{array}{l}\text { Decreased T2 pulvinar signal } \\
\text { intensity, mild cerebral } \\
\text { atrophy }\end{array}$ \\
\hline $16-19$ & $\begin{array}{l}\text { Edemic cheeks, cross } \\
\text { bite }\end{array}$ & No change & Angiokeratoma & $\begin{array}{l}\text { Thoracic } \\
\text { deformity }\end{array}$ & Psychotic periods, epilepsy & $\begin{array}{l}\text { Neutropenia, thrombopenia, } \\
\text { mild cerebellar atrophy }\end{array}$ \\
\hline $20-24$ & No change & $\begin{array}{l}\text { Coarsening } \\
\text { facial feature }\end{array}$ & $\begin{array}{l}\text { Facial } \\
\text { angiofibromas }\end{array}$ & $\begin{array}{l}\text { Childish } \\
\text { appearance }\end{array}$ & $\begin{array}{l}\text { Restless sleep, confusion } \\
\text { periods }\end{array}$ & $\begin{array}{l}\text { Evident cerebral and } \\
\text { cerebellar atrophy }\end{array}$ \\
\hline $25-34$ & No change & $\begin{array}{l}\text { Thick } \\
\text { eyebrows }\end{array}$ & Facial rosacea & Poor carriage & Epilepsy & - \\
\hline $35-44$ & $\begin{array}{l}\text { Loss of teeth and loss } \\
\text { of gingical overgrowts }\end{array}$ & $\begin{array}{l}\text { Thick and } \\
\text { broad/full lips }\end{array}$ & Loose skin & $\begin{array}{l}\text { Muscle atrophy } \\
\text { and hypotony }\end{array}$ & Bursitis, osteoporosis, orofacial & Attenuation in EEG \\
\hline $45+$ & Drooling & Microcephalia & $\begin{array}{l}\text { Angiofibromas } \\
\text { and rosacea } \\
\text { increse }\end{array}$ & $\begin{array}{l}\text { Contractures in } \\
\text { fingers and } \\
\text { elbows }\end{array}$ & $\begin{array}{l}\text { Abscesses, fistula of skin, } \\
\text { diarrhoea, anaemia, hearth } \\
\text { insufficiency, p }\end{array}$ & $\begin{array}{l}\text { Progression of cerebral and } \\
\text { cerebellar atrophy }\end{array}$ \\
\hline
\end{tabular}




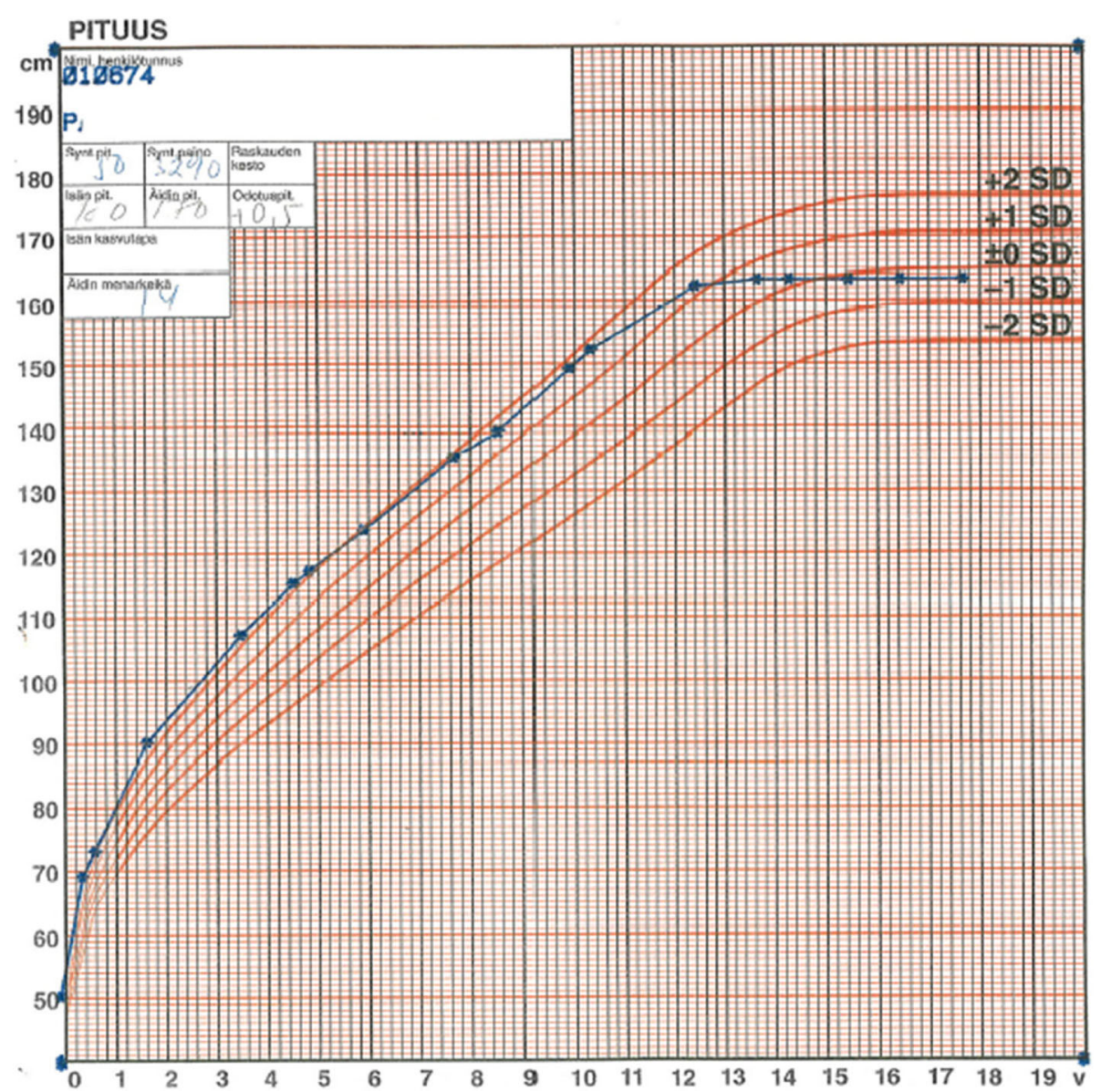

Fig. 1 A growth curve of a female AGU patient demonstrates excessive infantile growth, early but weak pubertal growth spurt, and reduced adult height

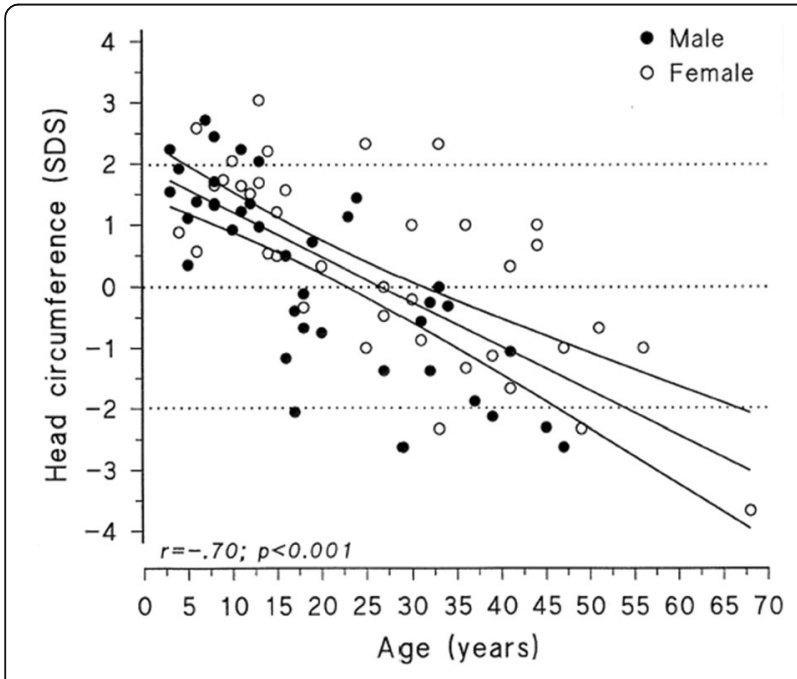

Fig. 2 Comparison of head circumferences (SD) of 78 AGU patients and Finnish normative data according chronological age shows macrocephaly in children and microcephaly in adults glycosylasparaginase enzyme protein. Site-directed mutagenesis and expression studies in COS cells demonstrated that only the cysteine to serine substitution (C163S) causes the deficiency of glycosylasparaginase activity [30]. The mutation destroys a disulfide bond [31] and leads to conformational changes in the inactive prercursor enzyme protein preventing its autocleavage into subunits and an active enzyme protein [32].

Screening of 115 Finnish AGU patients demonstrated that $98 \%$ of them were homozygous carrying the same two nucleotide changes (G482A and G488C) [33]. Thus, this so called $A G U_{\text {FIN }}$ major mutation is a result of a founder effect and demonstrates a high molecular homogeneity in the AGU alleles in the Finnish population. A genealogical study among nine AGU patients from seven families living in northern Norway, who were homozygous for the $A G U_{\text {FIN }}$ major mutation, proved Finnish ancestry in all pedigrees. These Finnish immigrants originated from northern Finland in a continuous immigration movement from 1700 to 1900 . The second AGU causing allele in the Finnish patients is a 2 base pair deletion in exon 2 of the gene $\left(\mathrm{AGU}_{\mathrm{FIN}}\right.$ minor 

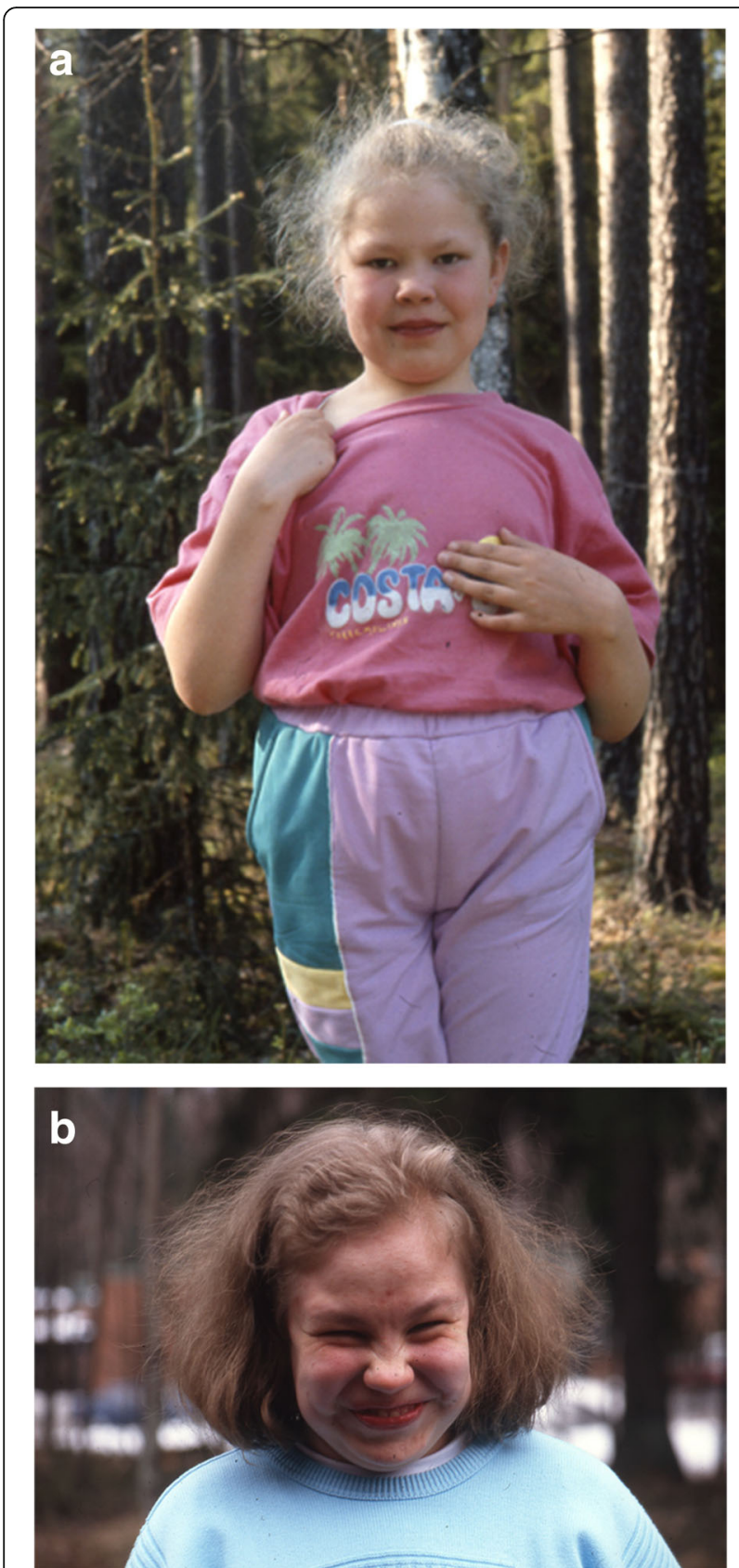

Fig. 3 a, b Consistent dysmorphic gestalt in AGU consists of hypertelorism, puffy eyelids, a short and broad nose with round nares

mutation) contributing to approximately $1.5 \%$ of the Finnish patients [34].

The data from the Human Gene Mutation Database (HGMD) [35] comprise currently more than 30 different AGU disease-causing mutations in the AGA gene. Half of them are missense mutations. The rest of them include small deletions and insertions, splicing mutations, gross deletions and complex rearrangements in the AGA gene. No genotype/phenotype correlations have been described so far.

\section{Glycosylasparaginase and pathophysiology of AGU}

AGA encodes an L-asparaginase (glycosylasparaginase), which catalyzes the hydrolysis of aspartylglucosamine and other glycoasparagines with s series of larger carbohydrate chains in lysosomes [3]. Glycosylasparaginase removes the L-asparagine moiety from glycoasparagines and L-aspartic acid, ammonia and free $\mathrm{N}$-acetylglucosamine or a carbohydrate chain is generated, respectively. Both the $\beta$-amino and $\beta$-carboxyl group of the L-asparagine moiety of the substrates must be free in order to enable their anchorage in the active site of glycosylasparaginase and their hydrolysis to occur [36, 37]. Therefore, complete proteolysis of the polypeptide chain surrounding each L-asparagine amino acid carrying an $\mathrm{N}$-glycosidic oligosaccharide moiety must always occur before the hydrolysis of the GlcNAc-Asn linkage. Glycolasparaginase also acts as an L-asparaginase and catalyzes the hydrolysis of free L-asparagine to L-aspartic acid and ammonia [38]. Based on the mechanism of action of glycosylasparaginase, a sensitive fluorometric to measure its activity has been developed using L-aspartic acid $\beta$ (7amino-4-methylcoumarin) as the substrate [39]. The combined evidence indicates that glycosylasparaginase reacts specifically toward the L-asparagine moiety of its substrates cleaving it with a mechanism of action similar to bacterial L-asparaginases. Thus the term "glycosylaspaganise" best describes its mode of action.

Glycosylasparaginase belongs to a superfamily of enzymes called as N-terminal nucleophile hydrolases [40, 41], since it catalytically uses a processed N-terminal threonine (Thr 206) $[27,36]$ as both a polarizing base and nucleophile to act on its subtrates.

The deficient activity of glycosylasparaginase activity results in accumulation of undegraded aspartylglucosamine and other glycoasparagines in body fluids and tissues of AGU patients [3] and AGU mouse model [42]. Hypertrophied storage lysosomes are present in all tissues and organs, but their morphology or histochemical properties are not diagnostic to distinguish the disease from many other lysosomal storage disorders.

\section{Animal model}

Research into the pathogenesis and therapy of AGU in humans was hampered until an animal model for the disease was developed through targeted disruption of the mouse Aga gene in embryonic stem cells [42]. The Aga-null - Aga (-/-) -mice completely lack glycosylasparaginase activity resulting in massive accumulation of aspartylglucosamine in their body fluids and tissues. The level of accumulation of GlcNAc-Asn in the Aga (-/-) mice is very comparable to that found in urine and tissues of human AGU patients.

Histopathological analyses using both light and electron microscopy demonstrated lysosomal hypertrophy in 
all visceral organs resembling that of human AGU. In the central nervous system (CNS), vacuolized neurons, glial cells and endothelial cells were observed in all regions studied including frontal cortex, cerebellum, brain stem and spinal cord. As a conclusion, the histological features including the distribution and appearance of the hypertrophic lysosomes of the Aga (-/-) closely resemble those in human AGU patients [43].

The early development of Aga (-/-) mice, like that of human AGU patients, did not show any significant phenotypic features. Starting at the age of 6 months, a gradual deterioration in condition leading to impaired neuromotor coordination, bladder function and premature death was observed in Aga (-/-) mice [44].

\section{Diagnosis and diagnostic methods}

Vacuolated cells, as in other lysosomal storage diseases, with expanded lysosomes can be detected in all AGU patient tissues in microscopic examinations. Biochemical diagnosis AGU is based on the examination of urinary oligosaccharides [45-47] and assay of glycosylasparaginase activity. Demonstration of accumulated aspartylglucosamine $[48,49]$ and other glycoasparagines in urine must lead to the measurement of glycosylasparaginase activity e.g., in serum, leukocytes or fibroblasts [50,51]. The enzyme assay in cultured amniotic fluid cells or chorionic villus samples $[52,53]$ or directly in amniotic fluid enable prenatal detection of the disease. The analysis of amniotic fluid glycoasparagines may not permit reliable diagnosis of AGU [54]. Analysis of urinary aspartylglucosamine or other glycoasparagines, or glycosylasparaginase activity e.g., in leukocytes [51], however, do not allow reliable carrier detection of AGU, but DNA tests are needed for that purpose. There are DNA tests available to detect the $\mathrm{AGU}_{\mathrm{FIN}}$ major mutation [27-29] and $\mathrm{AGU}_{\mathrm{FIN}}$ minor mutation [34] and carriers of those mutations $[55,56]$.

\section{Differential diagnosis}

An early growth spurt (Fig. 1) and development of macrocephalia (Fig. 2) followed by delayed speech development, physical clumsiness and exceptional placidity or periods of hyperactivity in a child with AGU-characteristic facial features (Fig. 3) usually rises a suspicion of AGU in Finland where the disease is well-known among child neurologists. The early signs in other diseases manifesting as intellectual disability included in the Finnish disease heritage, such as Salla disease, neuronal lipofuscinoses and Northern epilepsy, appear in another way. Poor eye contact, nystagmus, and ataxia associated to general muscle hypotony are the first signs in Salla disease; impaired vision in different types of neuronal lipofuscinoses; and epileptic seizures in Northern epilepsy.

The presence of vacuolated lymphocytes in peripheral blood and dilated, large lysosomes in tissue cells of a patient may be the first finding to indicate a lysosomal storage disease. A careful examination of the histology specimens may indicate whether the accumulating compound might be composed of lipids, glycosaminoglycas or oligosaccharides suggesting the further studies to identify the storage material. All disorders of glycoprotein degradation - including AGU - result in accumulation of oligosaccahrides in body fluids and tissues. Analysis of oligosaccharides in urine is best way to screen these disorders (see earlier). The same applies to such lysosomal storage disorders as certain types of gangliosidoses, sialic acid storage disorders and I-cell disease. Glycosaminoglycans in urine should also be analyzed to rule out various types of mucopolysaccharodoses. The identification of the structure of the accumulated material leads to specific enzyme analyses and the lack of the activity of a particular lysosomal enzyme activity finally confirms the correct diagnosis of the lysosomal disease. The assay of the activity of the missing enzyme - glycosylasparaginase can be used to diagnose other potential AGU patients in the family or prenatal testing. The sequence analysis of the cDNA or gene of the affected enzyme protein often reveals the mutation behind the structural defect in the enzyme protein and the analysis of this mutation can be used e.g., to carrier detection, prenatal diagnosis or diagnosis other affected individuals in the family.

\section{Management and treatment}

It is generally accepted that the intracellular accumulation of storage material -glycoasparagines - in the deficiency of glycosylasparaginase leads to the multisystem AGU disease characterized by progressive psychomotor retardation and structural changes in various tissues. Thus it is reasonable to assume that timely correction of the intracellular activity of glycosylasparaginase would prevent of the accumulation of glycoasparagines and thus the progression of the clinical symptoms of the AGU patients would cease and potentially reverse.

There is currently no curative treatment for human AGU disease. Some patients in Finland and Sweden have undergone bone marrow transplantation with no benefit $[57,58]$. Associated impairments like epileptic seizures, psychotic periods and arthritis are treated according general therapeutic guidelines. Carbamazepine has been used as a drug of choice effective in the treatment of epilepsy. The aim of rehabilitation and education is as proficient as possible mastery of social and independent living skills and good self-esteem. The rehabilitation plan is build individually and most often includes training at kindergarten and a special school for children with developmental disorders, speech and occupational therapy during childhood. Adult AGU patients often benefit from physio- and music therapy. 


\section{Experimental therapy}

In vitro experiments demonstrate that the metabolic defect in AGU fibroblasts and lymphocytes can effectively be corrected by enzyme replacement therapy with recombinant human glycosylasparaginase [59]. Correction of intracellular glycosylasparaginase activity to the level of 3-4\% of that in normal lymphocytes cleared cultured human AGU lymphocytes from intracellular aspartylglucosamine stores and its further accumulation was prevented. Cellto-cell transfer of glycosylasparaginase from normal to AGU cells occurs [60].

Recombinant human glycosylasparaginase is biologically active also in the experimental enzyme replacement therapy of the AGU mouse model [61]. Pathophysiologic characteristics of AGU were effectively corrected in nonneuronal tissues of adult AGU mice during 2 weeks of AGA therapy. At the same time, glycosylasparaginase activity increased to $10 \%$ of that in normal brain tissue and aspartylglucosamine amount was reduced by $20 \%$ in total brain of the treated Aga (-/-) mice. AGA therapy in newborn mice was even more effective reducing the amount of stored aspartylglucosamine in the brain tissue up to $40 \%$. The response to therapy was dose-dependent: the higher the glycosylasparaginase dose the faster the clearance of aspartylglucosamine [62]. Massive accumulation of a larger glycoasparagine (Man2GlcNAc-Asn) in tissues of AGU mice was also effectively corrected with glycosylasparaginase replacement therapy [63].

Interestingly, added glycosylasparaginase can induce apoptosis of L-asparagine-dependent leukemia cells in vivo by depleting the cells from their L-asparagine stores [64].

\section{Fetus and newborn}

AGU has been diagnosed prenatally demonstrating the deficiency of glycosylasparginase activity in cultured amniotic fluid cells [52,53]. Electron microscopic evidence of lysosomal storage was observed in several organs including kidneys of the fetus affected by AGU. Elevated amount of aspartylglucosamine in the midterm amniotic fluid from the pregnancy with the fetus affected by AGU further demonstrates of the presence of the metabolic defect of AGU prior to birth. Neonatal detection of AGU can be accomplished demonstrating lacking glycosylasparaginase activity in umbilical cord serum samples [65].

\section{Prognosis}

Table 1 summarizes various effects of the missing activity of glycosylasparaginase on the AGU patients. An AGU disease carrier may have a higher risk of arthritis and their facial bones show features characteristic to AGU disease $[5,18]$. Life expectancy for Finnish female patients is on the average 50 years and for men 45 years. The oldest known patient lived to the age of 69 years. Before death the patients usually experience a period of inactivity, poor general condition and fatigue. A dystonic status refractory to treatment may last for several days just before death. Autopsy findings if Finnish AGU patients suggest that the patients usually die of severe bacterial infections, mostly pulmonary infections.

\section{Future aspects}

Treatment of various lysosomal diseases has made a marked progress during the past two decades. The development of a variety of innovative therapeutic approaches include increasing the residual activity of the missing enzyme by stem cell transplantation, pharmacological chaperons, combination of chaperons and enzyme replacement therapy, substrate reduction therapy and gene therapy (for references [66]). Experience from these therapies will be beneficial in tackling the main limitations associated to enzyme replacement therapy in lysosomal diseases such as high cost, immunologic response and lack of efficacy to central nervous system. They represent significant challenges for future development of new drugs for treatment of AGU as well.

\section{Conclusions}

AGU studies have been conducted in many countries and new patients representing non-Finnish AGU mutations are frequently found. Although there is no curative treatment for this progressive disease it is considered important to share the information of its clinical course. The patients and their families can be supported in many ways, i.e., by providing both medical, educational and social services during the patient's life span. Most health issues associated with AGU, e.g., like epilepsy, rheumatoid arthritis, and infections, can be treated according to general guidelines. On the other hand, it may help families to overcome the difficult phases of disease's course to know that the stressful, drug-refractory manic-apathetic periods, which are known

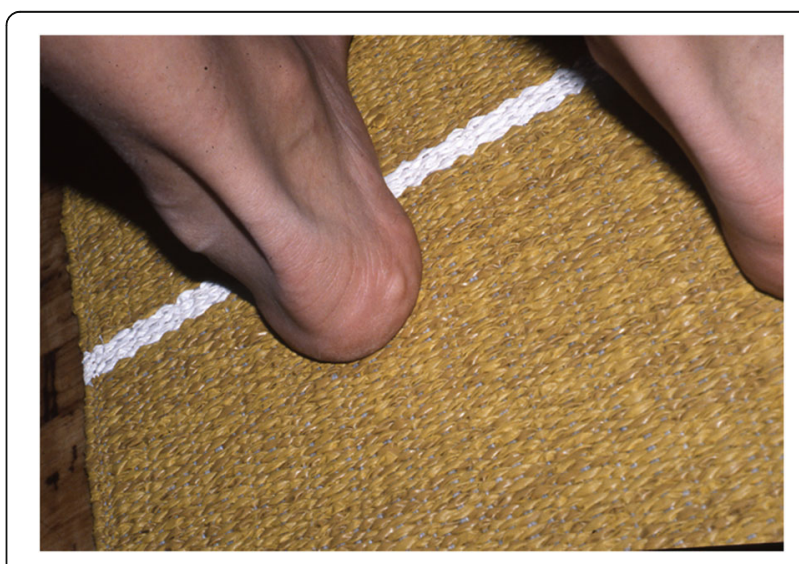

Fig. 4 Piezogymic papules in heel in a patient with AGU 


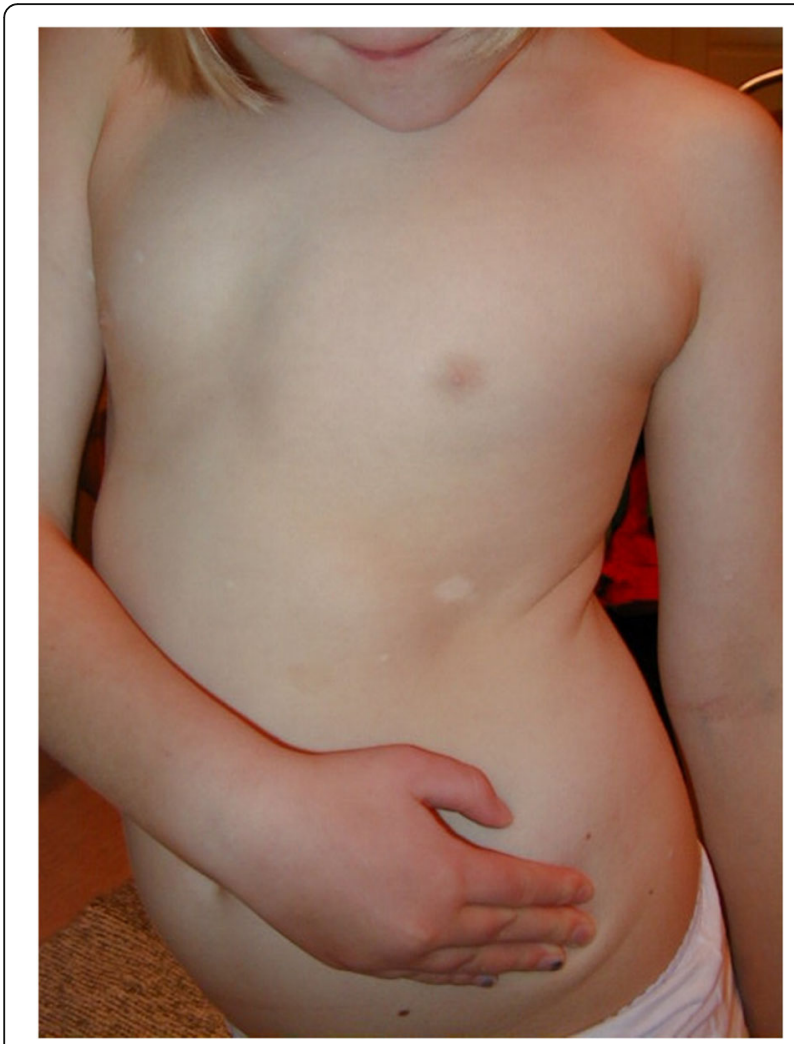

Fig. 5 White skin spot in a patient with AGU

to affect about $20 \%$ of patients during their adolescent years, usually subside in young adulthood. Also, physiotherapy and other therapies thorough life can often be beneficial. The great importance of peer support of the family association should not be forgotten either. From the socioeducational perspective the burden of parents can be eased by individually tailored learning goals in early childhood and in adolescence by organizing suitable daily activities in group homes and/or day care centers. Later on most of the diseased persons need a nursing home. Once the special needs of the patients are met and treated, they themselves are usually quite satisfied with their daily living. Successful therapy of AGU will require therapeutic strategies, which effectively increase glycosylasparaginase activity in central nervous system.

\section{Abbreviations}

AGA: Glycosylasparaginase, Aspartylglucosaminidase;

AGU: Aspartylglucosaminuria, Aspartylglycosaminuria; GlcNAc-Asn: 2acetamido-1-( $\beta^{\prime}$-L-aspartamido)-1,2-didieoxyglucose, Aspartylglucosamine: MRI: Magnetic resonance image

\section{Acknowledgements}

The authors thank the AGU family members who have participated in the studies described in the report and all the scientists in the field of AGU research who have contributed to our current knowledge of the disease

\section{Funding}

The authors received no funding for the preparation of this review article.

Availability of data and materials

Data sharing not applicable to this article as no datasets were generated or analysed during the current study.

\section{Authors' contributions}

MA and IM equally contributed to this manuscript. Both authors read and approved the final manuscript.

\section{Competing interests}

The authors declare that they have none competing interests.

\section{Consent for publication}

Written informed consent was obtained from the patients and patients parents for publication of the images in Figs. 3, 4 and 5. A copy of written consent is available for review by the Editor-In-Chief of this journal.

Ethics approval and consent to participate

Not applicable.

\section{Author details}

${ }^{1}$ Päijät-Häme Social Welfare \& Healthcare Joint Municipal Board, Lahti, Finland. ${ }^{2} \mathrm{KTO}$, The Special Welfare District of Southwestern Finland, Paimio, Finland. ${ }^{3}$ PEDEGO Research Unit, Oulu University Hospital, Finland, Oulu, Finland. ${ }^{4}$ Newborn Screening Center Finland, Saske, Turku University Central Hospital, Turku, Finland. ${ }^{5}$ The Joint Clinical Chemistry Laboratory at Turku University Hospital, Turku, Finland. ${ }^{6}$ Department of Clinical Chemistry, University of Turku, PO Box 52FIN-20521 Turku, Finland.

Received: 22 June 2016 Accepted: 16 November 2016

Published online: 01 December 2016

\section{References}

1. Pollitt RJ, Jenner FA, Merskey $H$. Aspartylglycosaminuria. An inborn error of metabolism associated with mental defect. Lancet. 1968;2(7562):253-5.

2. Palo J. Prevalence of phenylketonuria and some other metabolic disorders among mentally retarded patients in Finland. Acta Neurol Scand. 1967:43(5):573-9.

3. Mononen I, Fisher KJ, Kaartinen V, Aronson Jr NN. Aspartylglycosaminuria: protein chemistry and molecular biology of the most common lysosomal storage disorder of glycoprotein degradation. FASEB J. 1993;7(13):1247-56

4. Mononen I. Aronson NN, editors. Lysosomal storage disease: Aspartylglycosaminuria. Heidelberg: Spirenger-Verlag; 1997

5. Arvio M, Laiho K, Kauppi M, Peippo M, Leino P, Kautiainen H, KaipiainenSeppanen O, Mononen I. Carriers of the aspartylglucosaminuria genetic mutation and chronic arthritis. Ann Rheum Dis. 2002;61(2):180-1.

6. Peltonen L. Molecular background of the Finnish disease heritage. Ann Med. 1997:29(6):553-6.

7. Borud O, Torp KH. Letter: aspartylglycosaminuria in Northern Norway. Lancet. 1976;1(7968):1082-3.

8. Mononen T, Mononen I, Matilainen R, Airaksinen E. High prevalence of aspartylglycosaminuria among school-age children in eastern Finland. Hum Genet. 1991:87(3):266-8

9. Hietala M, Gron K, Syvanen AC, Peltonen L, Aula P. Prospects of carrier screening of aspartylglucosaminuria in Finland. Eur J Hum Genet. 1993;1(4):296-300.

10. Kallinen J, Heinonen S, Palotie A, Mannermaa A, Ryynanen M. Antenatal gene tests in low-risk pregnancies: molecular screening for aspartylglucosaminuria (AGU) and infantile neuronal ceroid lipofuscinosis (INCL) in Finland. Prenat Diagn. 2001;21(5):409-12.

11. Arvio P, Arvio M. Progressive nature of aspartylglucosaminuria. Acta Paediatr. 2002;91(3):255-7.

12. Arvio P, Arvio M, Kero M, Pirinen S, Lukinmaa PL. Overgrowth of oral mucosa and facial skin, a novel feature of aspartylglucosaminuria. J Med Genet. 1999:36(5):398-404

13. Arvio $P$, Anvio M, Pirinen S. Characteristic dental arches and occlusion in patients with aspartylglucosaminuria. J Craniofac Genet Dev Biol. 1997:17(3):133-40.

14. Arvio P, Arvio M, Marttinen E, Sipila I, Pirinen S. Excessive infantile growth and early pubertal growth spurt: typical features in patients with aspartylglycosaminuria. J Pediatr. 1999;134(6):761-3. 
15. Arvio M, Autio S, Louhiala P. Early clinical symptoms and incidence of aspartylglucosaminuria in Finland. Acta Paediatr. 1993;82(6-7):587-9.

16. Arvio M. Follow-up in patients with aspartylglucosaminuria. Part I. The course of intellectual functions. Acta Paediatr. 1993;82(5):469-71.

17. Arvio M. Follow-up in patients with aspartylglucosaminuria. Part II. Adaptive skills. Acta Paediatr. 1993;82(6-7):590-4.

18. Arvio MA, Peippo MM, Arvio PJ, Kaariainen HA. Dysmorphic facial features in aspartylglucosaminuria patients and carriers. Clin Dysmorphol. 2004;13(1):11-5.

19. Arvio M, Oksanen V, Autio S, Gaily E, Sainio K. Epileptic seizures in aspartylglucosaminuria: a common disorder. Acta Neurol Scand. 1993;87(5):342-4.

20. Arvio MA, Rapola JM, Pelkonen PM. Chronic arthritis in patients with aspartylglucosaminuria. J Rheumatol. 1998;25(6):1131-4

21. Arvio P, Arvio M, Wolf J, Lukinmaa PL, Saxen L, Pirinen S. Impaired oral health in patients with aspartylglucosaminuria. Oral Surg Oral Med Oral Pathol Oral Radiol Endod. 1998:86(5):562-8.

22. Lindblom N, Kivinen S, Heiskala H, Laakso ML, Kaski M. Sleep disturbances in aspartylglucosaminuria (AGU): a questionnaire study. J Inherit Metab Dis. 2006;29(5):637-46.

23. Ambrosetto G, Santucci M. Sleep-related hypermotor seizures in aspartylglucosaminuria: a case report. Epilepsia. 2009;50(6):1638-40.

24. Tokola AM, Aberg LE, Autti TH. Brain MRI findings in aspartylglucosaminuria. J Neuroradiol. 2015;42(6):345-57.

25. Arvio M, Arvio P, Hurmerinta K, Pirinen S, Sillanpaa M. Reduction in head size in patients with aspartylglucosaminuria. Acta Neurol Scand. 2005;1 12(5):335-7.

26. Liu Y, Dunn GS, Aronson Jr NN. Purification, biochemistry and molecular cloning of an insect glycosylasparaginase from Spodoptera frugiperda. Glycobiology. 1996;6(5):527-36.

27. Mononen I, Heisterkamp N, Kaartinen V, Williams JC, 3rd Yates JR, Griffin PR, Hood LE, Groffen J. Aspartylglycosaminuria in the Finnish population: identification of two point mutations in the heavy chain of glycoasparaginase. Proc Natl Acad Sci U S A. 1991;88(7):2941-5.

28. Fisher KJ, Tollersrud OK, Aronson Jr NN. Cloning and sequence analysis of a cDNA for human glycosylasparaginase. A single gene encodes the subunits of this lysosomal amidase. FEBS Lett. 1990;269(2):440-4

29. Ikonen E, Baumann M, Gron K, Syvanen AC, Enomaa N, Halila R, Aula P, Peltonen L. Aspartylglucosaminuria: CDNA encoding human aspartylglucosaminidase and the missense mutation causing the disease. EMBO J. 1991;10(1):51-8.

30. Fisher KJ, Aronson Jr NN. Characterization of the mutation responsible for aspartylglucosaminuria in three Finnish patients. Amino acid substitution Cys163_- Ser abolishes the activity of lysosomal glycosylasparaginase and its conversion into subunits. J Biol Chem. 1991;266(18):12105-13.

31. McCormack AL, Mononen I, Kaartinen V, 3rd Yates JR. Localization of the disulfide bond involved in post-translational processing of glycosylasparaginase and disrupted by a mutation in the Finnish-type aspartylglycosaminuria. J Biol Chem. 1995;270(7):3212-5.

32. Sui L, Lakshminarasimhan D, Pande S, Guo HC. Structural basis of a point mutation that causes the genetic disease aspartylglucosaminuria. Structure. 2014;22(12):1855-61

33. Syvanen AC, Ikonen E, Manninen T, Bengtstrom M, Soderlund $H$, Aula $P$, Peltonen L. Convenient and quantitative determination of the frequency of a mutant allele using solid-phase minisequencing: application to aspartylglucosaminuria in Finland. Genomics. 1992;12(3):590-5.

34. Isoniemi A, Hietala M, Aula P, Jalanko A, Peltonen L. Identification of a nove mutation causing aspartylglucosaminuria reveals a mutation hotspot region in the aspartylglucosaminidase gene. Hum Mutat. 1995;5(4):318-26.

35. Stenson PD, Mort M, Ball EV, Shaw K, Phillips A, Cooper DN. The human gene mutation database: building a comprehensive mutation repository for clinical and molecular genetics, diagnostic testing and personalized genomic medicine. Hum Genet. 2014;133(1):1-9.

36. Kaartinen V, Williams JC, Tomich J, 3rd Yates JR, Hood LE. Mononen I. Glycosaparaginase from human leukocytes. Inactivation and covalent modification with diazo-oxonorvaline. J Biol Chem. 1991;266(9):5860-9.

37. Kaartinen V, Mononen T, Laatikainen R, Mononen I. Substrate specificity and reaction mechanism of human glycoasparaginase. The $\mathrm{N}$-glycosidic linkage of various glycoasparagines is cleaved through a reaction mechanism similar to L-asparaginase. J Biol Chem. 1992;267(10):6855-8.

38. Noronkoski T, Stoineva IB, Petkov DD, Mononen I. Recombinant human glycosylasparaginase catalyzes hydrolysis of L-asparagine. FEBS Lett. 1997; 412(1):149-52.
39. Mononen IT, Kaartinen VM, Williams JC. A fluorometric assay for glycosylasparaginase activity and detection of aspartylglycosaminuria. Anal Biochem. 1993;208(2):372-4.

40. Brannigan JA, Dodson G, Duggleby HJ, Moody PC, Smith JL, Tomchick DR, Murzin AG. A protein catalytic framework with an $\mathrm{N}$-terminal nucleophile is capable of self-activation. Nature. 1995;378(6555):416-9.

41. Oinonen C, Rouvinen J. Structural comparison of Ntn-hydrolases. Protein Sci. 2000;9(12):2329-37.

42. Kaartinen V, Mononen I, Voncken JW, Noronkoski T, Gonzalez-Gomez I, Heisterkamp N, Groffen J. A mouse model for the human lysosomal disease aspartylglycosaminuria. Nat Med. 1996;2(12):1375-8.

43. Gonzalez-Gomez I, Mononen I, Heisterkamp N, Groffen J, Kaartinen V. Progressive neurodegeneration in aspartylglycosaminuria mice. Am J Pathol. 1998;153(4):1293-300.

44. Kaartinen V, Mononen I, Gonzalez-Gomez I, Noronkoski T, Heisterkamp N, Groffen J. Phenotypic characterization of mice with targeted disruption of glycosylasparaginase gene: a mouse model for aspartylglycosaminuria. J Inherit Metab Dis. 1998;21(3):207-9.

45. Sewell AC. Simple laboratory determination of excess oligosacchariduria. Clin Chem. 1981;27(2):243-5.

46. Xia B, Asif G, Arthur L, Pervaiz MA, Li X, Liu R, Cummings RD, He M. Oligosaccharide analysis in urine by maldi-tof mass spectrometry for the diagnosis of lysosomal storage diseases. Clin Chem. 2013;59(9):1357-68.

47. Mononen I, Kaartinen V, Mononen T. Laboratory detection of aspartylglycosaminuria. Scand J Clin Lab Invest Suppl. 1988;191:7-11.

48. Kaartinen V, Mononen I. Analysis of aspartylglucosamine at the picomole level by high-performance liquid chromatography. J Chromatogr. 1989; 490(2):293-9.

49. Mononen T, Parviainen M, Penttila I, Mononen I. Liquid-chromatographic detection of aspartylglycosaminuria. Clin Chem. 1986;32(3):501-2.

50. Kaartinen $\mathrm{V}$, Mononen I. Assay of aspartylglycosylaminase by highperformance liquid chromatography. Anal Biochem. 1990;190(1):98-101.

51. Mononen I, Mononen T, Ylikangas P, Kaartinen V, Savolainen K. Enzymatic diagnosis of aspartylglycosaminuria by fluorometric assay of glycosylasparaginase in serum, plasma, or lymphocytes. Clin Chem. 1994; 40(3):385-8.

52. Aula P, Rapola J, von Koskull H, Ammala P. Prenatal diagnosis and fetal pathology of aspartylglucosaminuria. Am J Med Genet. 1984;19(2):359-67.

53. Aula P, Mattila K, Piiroinen O, Ammala P, Von Koskull H. First-trimester prenatal diagnosis of aspartylglucosaminuria. Prenat Diagn. 1989;9(9):617-20.

54. Mononen I, Kaartinen $\mathrm{V}$, Mononen T. Amniotic fluid glycoasparagines in fetal aspartylglycosaminuria. J Inherit Metab Dis. 1988;11(2):194-8.

55. Delahunty CM, Ankener W, Brainerd S, Nickerson DA, Mononen IT. Finnishtype aspartylglucosaminuria detected by oligonucleotide ligation assay. Clin Chem. 1995;41(1):59-61.

56. Hietala M, Aula P, Syvanen AC, Isoniemi A, Peltonen L, Palotie A. DNA-based carrier screening in primary healthcare: screening for aspartylglucosaminuria mutations in maternity health offices. Clin Chem. 1996;42(9):1398-404.

57. Arvio M, Sauna-Aho O, Peippo M. Bone marrow transplantation for aspartylglucosaminuria: follow-up study of transplanted and nontransplanted patients. J Pediatr. 2001;138(2):288-90.

58. Ringden O, Remberger M, Svahn BM, Barkholt L, Mattsson J, Aschan J, Le Blanc K, Gustafsson B, Hassan Z, Omazic B, Svenberg P, Solders G, von Dobeln U, Winiarski J, Ljungman P, Malm G. Allogeneic hematopoietic stem cell transplantation for inherited disorders: experience in a single center. Transplantation. 2006;81(5):718-25.

59. Mononen I, Heisterkamp N, Dunder U, Romppanen EL, Noronkoski T, Kuronen I, Groffen J. Recombinant glycosylasparaginase and in vitro correction of aspartylglycosaminuria. FASEB J. 1995;9(5):428-33.

60. Dunder U, Mononen I. Human leukocyte glycosylasparaginase: cell-to-cell transfer and properties in correction of aspartylglycosaminuria. FEBS Lett. 2001:499(1-2):77-81.

61. Dunder U, Kaartinen V, Valtonen P, Vaananen E, Kosma VM, Heisterkamp N, Groffen J, Mononen I. Enzyme replacement therapy in a mouse model of aspartylglycosaminuria. FASEB J. 2000;14(2):361-7.

62. Dunder U, Valtonen P, Kelo E, Mononen I. Early initiation of enzyme replacement therapy improves metabolic correction in the brain tissue of aspartylglycosaminuria mice. J Inherit Metab Dis. 2010;33(5):611-7.

63. Kelo E, Dunder U, Mononen I. Massive accumulation of Man2GlcNAc2-Asn in nonneuronal tissues of glycosylasparaginase-deficient mice and its removal by enzyme replacement therapy. Glycobiology. 2005;15(1):79-85. 
64. Kelo E, Noronkoski T, Mononen I. Depletion of L-asparagine supply and apoptosis of leukemia cells induced by human glycosylasparaginase. Leukemia. 2009;23(6):1167-71.

65. Mononen I, Ylikangas P, Mononen T, Savolainen K. Neonatal detection of aspartylglycosaminuria. Lancet. 1994;343(8908):1297-8.

66. Parenti G, Pignata C, Vajro P, Salerno M. New strategies for the treatment of lysosomal storage diseases (Review). Int J Mol Med. 2013;31:11-20.

Submit your next manuscript to BioMed Central and we will help you at every step:

- We accept pre-submission inquiries

- Our selector tool helps you to find the most relevant journal

- We provide round the clock customer support

- Convenient online submission

- Thorough peer review

- Inclusion in PubMed and all major indexing services

- Maximum visibility for your research

Submit your manuscript at www.biomedcentral.com/submit
C Biomed Central 